\title{
Landslide Potential in Santo Domingo De Heredia, Costa Rica, Central America
}

\author{
Jonnathan Reyes-Chaves ${ }^{2} \&$ Mario Fernández-Arce ${ }^{1,2,3}$ \\ ${ }^{1}$ Preventec-University of Costa Rica (UCR), Costa Rica \\ ${ }^{2}$ School of Geography, University of Costa Rica (UCR), Costa Rica \\ ${ }^{3}$ Center for Research in Geological Sciences (UCR), Costa Rica \\ Correspondence: Mario Fernández-Arce, School of Geography, University of Costa Rica (UCR), Costa Rica. \\ E-mail: mario.fernandezarce@ucr.ac.cr
}

Received: June 20, 2014 Accepted: July 11, 2014 Online Published: October 19, 2014

doi:10.5539/jgg.v6n4p1 URL: http://dx.doi.org/10.5539/jgg.v6n4p1

\begin{abstract}
This paper reports results from a survey of landslide potential in the canton (county) of Santo Domingo de Heredia, Costa Rica. This canton, like much of Central America, is located in a tropical region with abrupt topography where the potential for landslides is relatively high. A deadly landslide occurred in this canton in 2008. Due to this reality, it is important to investigate the landslide potential in the canton more broadly. This action study will contribute to the efforts of local authorities to manage disaster risk in the study area. The purpose of the work is to spatially identify the areas at risk to this hazard, with the long-term goal of reducing the human vulnerability and enhancing protective actions for people living near the zones at high risk for landslide. The Mora-Varhson-Mora methodology, which takes into account lithology, humidity, slope, seismicity and precipitation to estimate landslide potential, was used to carry out the work. The most important results are that the landslide potential overall in Santo Domingo is low but that there are specific communities with high risk; these include Fatima, Monte Carmelo, Calle Vieja and La Presa.
\end{abstract}

Keywords: landslides, susceptibility, vulnerability, potential, slope, stability

\section{Introduction}

Landslides are a very common natural threat around the world, especially in tropical countries with mountain belts of abrupt relief (Larsen and Torres, 1998, Dai et al., 2002). Guzzetti (2000) indicated that landslide disasters often occur when cut slopes fail in highly urbanized areas. If people live on slopes prone to landslides, or near the base of a slope prone to sliding, they are vulnerable to the catastrophic impact of a sudden landslide. Rosenfeld (1994) and Alexander (1995) said that the population growth and the expansion of settlements and life-lines over hazardous areas are increasing the impact of natural disasters, both in the developed and developing world (Rosenfeld, 1994; Alexander, 1995 in Guzzetti et al., 1999). Therefore, it is necessary to recognize the landslide potential of landslide prone areas to protect the population and prevent deaths.

There are many case studies of individual landslides in Costa Rica (Mora et al., 1989; Mora et al., 1990, Mora \& Soto, 1990; Mora, 1993, Peraldo \& Molina, 1993; Mands et al., 1994; Mora, 2001; Alvarado et al., 2003) but no current scientific publications on the landslide potential of the study area. The working hypotheses is that the landslide susceptibility (Carrara, 1993; Pradhan, 2010) of Santo Domingo (Figure 1) is low despite the high levels of precipitation and seismicity in the country but zones of high potential exist in the steep slope areas, especially along river canyons. Such hypotheses will be tested as we map landslide potential and identify areas at risk. 


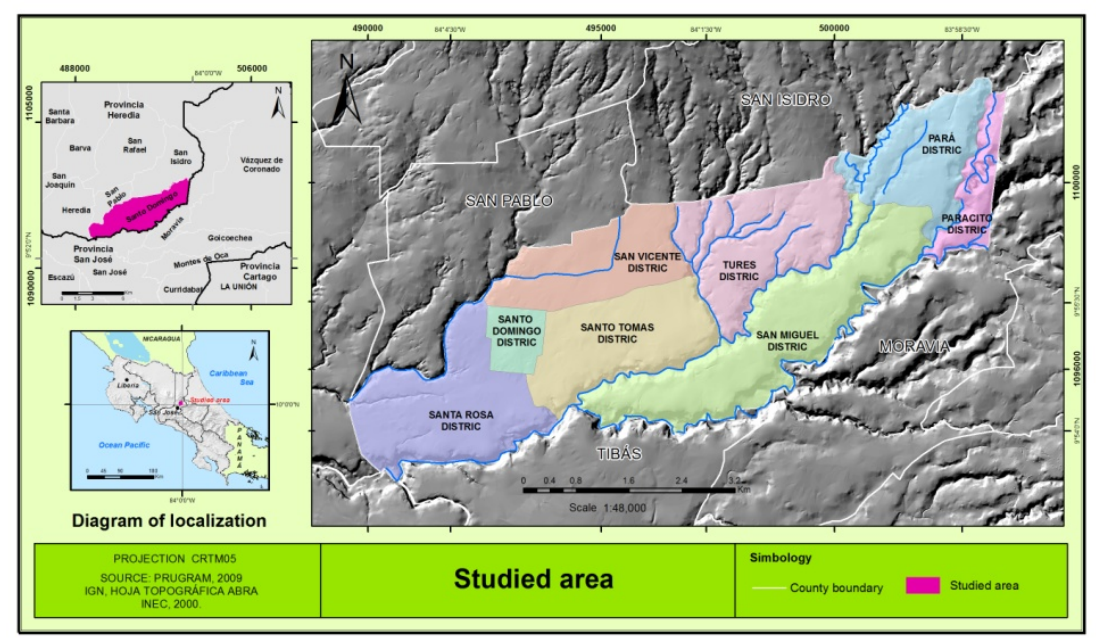

Figure 1. The territory of Santo Domingo and the districts of the county

The research design necessitates assessing susceptibility factors as the lithology, soil moisture, slope angles, precipitation levels and seismic intensities of the study area. All these factors will be considered in our assessment of landslide potential in Santo Domingo. From a theoretical point of view, the study will allow us to evaluate the methodology to determine landslide susceptibility and verify that the theoretical foundation of such methodology is based on a cause-effect relationship. With regard to the practical implications of the research, the results will be useful for disaster risk management in the canton.

In tropical countries of abrupt relief like Costa Rica, low per capita incomes combine with high risk of landslides; it is therefore imperative to competently assess the landslide potential at the canton level. It is essential for risk management agents, if they want to avoid death due to landslides. All canton governments in Costa Rica are required by law to manage disaster risks within their jurisdiction, including the risks to life and property which can be caused as landslides, but few have the necessary information to do so. In this type of study, which aims to prevent deaths caused by landslides, predicting the future occurrence of landslides is more essential than studying past landslides.

A method for estimating the susceptibility to landslides which considered the lithology, relief (Guzzetti et al., 2005), soil moisture, seismicity and precipitation (Mora and Varhson, 1991), was proposed in Costa Rica at the beginning of the 1990s. In 1992, the method was slightly modified to include the slope's angle and consideration of direct shear strength and classification of the rock mass in the lithological susceptibility parameter of the model (Mora et al., 1992). Since then, this methodology has been used to estimate landslide risk in areas of significant size, like a canton (Mora et al., 2002; Segura et al., 2011; Barrantes et al., 2011). Previous studies concluded that the Mora-Vahrson-Mora methodology is highly reliable to estimate landslide potential in large areas like cantons. It is common knowledge that Santo Domingo is susceptible to landslides, but it has never been systematically studied. To do so, we employ an indirect method to generate information about susceptibility and to identify areas at different degrees of risk for landslide potential. With the generated information, we can prepare thematic maps with overlapping layers in order to establish the degree of susceptibility on the basis of the unique contribution of each if the susceptibility factors.

\section{Methodology}

To estimate landslide potential we used the Mora-Vahrson-Mora methodology (Mora et al. 1992) which asserts that landslides occur when a slope, composed with a particular lithology, with some degree of humidity, reaches a degree of susceptibility. Under these conditions, dynamic and external processes like seismic activity and heavy rainfall can act as triggering factors (Guzzetti, 2000; Guzzetti et al.; 2005, Dasa et al., 2010) that disrupt the fragile balance, and cause a landslide (Mora, et al., 1992).

Thus, the degree of susceptibility of a slope to slip $(\mathrm{H})$ is a product of the passive elements (PE) and the trigger factors (D), as it is indicated in the following equation: 


$$
\mathrm{H}=\mathrm{PE} * \mathrm{D}
$$

Where:

$\mathrm{H}$ : the degree of susceptibility of a slope to slip,

PE: passive elements

D: trigger factor (active elements).

On the other hand, the value of passive elements is made up of the following parameters:

$$
\mathrm{PE}=\mathrm{ls} * \mathrm{hs} * \mathrm{ps}
$$

Where:

ls : lithological susceptibility,

hs : soil moisture

ps : angle of the slope.

The trigger factor is composed of the following parameters:

$$
\mathrm{D}=\mathrm{Ds}+\mathrm{Dll}
$$

where:

Ds : trigger by seismicity

Dll : trigger by rain.

Substituting the appropriate parameters, the original equation can be expressed as:

$$
\mathrm{H}=(\mathrm{ls} * \mathrm{hs} * \mathrm{ps}) *(\mathrm{Ds}+\mathrm{D} 1 \mathrm{l})
$$

The following relationships can be derived from the prior equation:

$$
\begin{aligned}
& \mathrm{Hs}=(\mathrm{ls} * \mathrm{hs} * \mathrm{ps}) *(\mathrm{Ds}) \\
& \mathrm{Hll}=(\mathrm{ls} * \mathrm{hs} * \mathrm{ps}) *(\mathrm{Dll})
\end{aligned}
$$

where:

Hs: susceptibility to slip by seismicity

Hll: susceptibility to slip by rain.

We used geological information of Arias and Denyer (1991), Pérez et al. (2004) and Astorga et al. (2011).

This methodology is valuable in the identification of critical areas and useful in the orientation of priorities on the use of the resources devoted to geotechnical studies of detail. Under any circumstances, this methodology should replace geotechnical field and laboratory testing necessary for the design and conception of structures and

\begin{tabular}{|c|c|c|}
\hline $\begin{array}{l}\text { Score } \\
\text { and } 1 \\
\text { value }\end{array}$ & Lithology & $\begin{array}{l}\text { Typical physic- } \\
\text { mechanic characteristics }\end{array}$ \\
\hline $\begin{array}{l}\text { Low } \\
\text { ls }=1\end{array}$ & $\begin{array}{l}\text { Alluvium: thick, permeable, compact, low phreatic level. } \\
\text { Limestone: hard, permeable. } \\
\text { Intrusive: little fissured, low phreatic level. } \\
\text { Basalts, andesite, ignimbrite and similar: healthy, permeable and } \\
\text { few fissured. } \\
\text { Metamorphic rocks: healthy, little fissured, low phreatic level. }\end{array}$ & $\begin{array}{l}\text { Healthy with little or no } \\
\text { weathering, high shear } \\
\text { strength, healthy cracks } \\
\text { without fillers. }\end{array}$ \\
\hline $\begin{array}{l}\text { Moderate } \\
\quad l s=2\end{array}$ & $\begin{array}{l}\text { Sedimentary rocks: little altered, solid stratification (decametric or } \\
\text { metric), little cracked, low water level. Intrusive rocks, limestone } \\
\text { hard, lava and ignimbrites or metamorphic: mildly cracked or }\end{array}$ & $\begin{array}{l}\text { Medium or high shear } \\
\text { strength, Medium to high } \\
\text { resistance to cutting, }\end{array}$ \\
\hline
\end{tabular}
infrastructure (Mora et al., 2002).

\subsection{Parameter Operationalization}

The lithological susceptibility (ls) is estimated according to the type of rock and its typical physical and mechanical characteristic (Table 1).

Table 1. Classification of the lithological factor ls. Source: Mora, et al., (1992) 
altered groundwater level to intermediate depths.

Medium Sedimentary rocks, intrusive rocks, metamorphic rocks, hard ls $=3$ limestone, lava, ignimbrites, little welded tuffs. Rocks moderately altered. Colluvium, lahars, sands, regolith soils slightly compacted. Drainage little developed relatively high groundwater levels.

High Fluvial-lacustrine alluvium, little compacted pyroclastic soils, areas ls $=4 \quad$ of hydrothermal alteration, rocks strongly altered and fractured with stratifications and foliation in the direction of the slope. The fractures are filled with clay. Shallow groundwater levels.

Very high Alluvial, colluvial and regolith materials with very low mechanical ls $=5$ quality with high weathering grade, poor drainage, and include the characteristics of categories 3 and 4 (above) with very shallow water table levels, subject to very high hydrodynamic gradients. shareable fractures.

Shear strength: moderate to medium, major fracturing.

Shear strength: moderate to low.

Shear strength: very low, soft materials with many fine (material).

The soil moisture (hs) is determined from monthly precipitation averages (Table 2). We used them to calculate a simplified hydric balance in which a potential evapotranspiration of $125 \mathrm{~mm}$ per month is assumed. According to the Mora-Varhson-Mora methodology, less than $125 \mathrm{~mm}$ rainfall per month does not lead to an increase in ground moisture (assigned value $=0$ ), while precipitation amounts between 125 and 250 mm notably increase the soil moisture (assigned value $=1$ ), and more than $250 \mathrm{~mm}$ of monthly rainfall leads to high levels of soil moisture (assigned value $=2$ ). Then, the values assigned to the monthly averages were summed for the twelve months of the year, which produce a value which can vary between 0 and 24 units. The categories of soil moisture are as follow: very low, low, medium, high, very high (Table 3). The result reflects saturation and the temporal distribution of moisture in the ground (Mora, et al., 1992).

Table 2. Values assigned to the monthly rain averages. Source: Mora, et al., (1992)

\begin{tabular}{cc}
\hline $\begin{array}{c}\text { Monthly rain average } \\
{[\mathrm{mm}]}\end{array}$ & Assigned value \\
\hline$<125$ & 0 \\
$125-250$ & 1 \\
$>250$ & 2 \\
\hline
\end{tabular}

Table 3. Assessment of the hs parameter. Source: Mora, et al., (1992)

\begin{tabular}{ccc}
\hline $\begin{array}{c}\text { Sum of assigned values for } \\
\text { each month }\end{array}$ & Description & Assessment of the parameter hs \\
\hline $0-4$ & Very low & 1 \\
$5-9$ & Low & 2 \\
$10-14$ & Medium & 3 \\
$15-19$ & High & 4 \\
$20-24$ & Very high & 5 \\
\hline
\end{tabular}

The slope parameter (ps) uses the a classification scheme called van Zuidam to characterize slope, which uses a legend of colors corresponding to the type of slope. The angle of the slope corresponds to ps as follows: $0-2$ ps $=0$, $2-4 \mathrm{ps}=1,4-8 \mathrm{ps}=2,8-16 \mathrm{ps}=3$ and $16-35 \mathrm{ps}=4$ (Table 4$)$.

Table 4. Information uses to assess the parameter ps. Fuente: Mora, et al. (2002)

\begin{tabular}{|c|c|c|c|c|}
\hline \multicolumn{2}{|c|}{ Slope class } & \multirow[t]{2}{*}{ Soil conditions } & \multirow{2}{*}{$\begin{array}{l}\text { Suggested } \\
\text { color }\end{array}$} & \multirow{2}{*}{$\begin{array}{l}\text { Value of the } \\
\text { parameter ps }\end{array}$} \\
\hline Angle & Percentage & & & \\
\hline $0-2$ & $0-2$ & Plain, no visible denudation & Dark Green & 0 \\
\hline $2-4$ & $2-7$ & Very low slope, some danger of erosion & Light Green & 1 \\
\hline $4-8$ & $7-15$ & Low slope, danger of severe erosion & Yellow & 2 \\
\hline $8-16$ & $15-30$ & Moderate slope, sporadic & Orange & 3 \\
\hline
\end{tabular}




\begin{tabular}{ccl}
\hline 16-35 $30-70$ & $\begin{array}{l}\text { danger of severe erosion. } \\
\text { High slope, intense denudational Light Red } \\
\text { processes (landslides), danger of extreme } \\
\text { erosion of soils. }\end{array}$ & 4 \\
Very high slope, rocky out crops, intense Dark Red \\
denudational processes, possible \\
reforestation \\
Extremely high slope, rocky out crops, Purple \\
intense denudational processes (rock \\
fall), limited vegetal coverage.
\end{tabular}

The landslides potential due to seismic activity (Ds) can be correlated with the Mercalli-modified scale of intensities (I). Per degree of intensity, the methodology assigns an equal value to the parameter Ds, for example, $\mathrm{I}=1$ then Ds $=1 ; \mathrm{I}=2$ then Ds $=2$, etc... $($ Table 5$)$.

Table 5. Assessment of the parameter Ds Source: Mora, et al., (1992)

\begin{tabular}{ccc}
\hline $\begin{array}{c}\text { Intensity } \\
\text { Mercalli - Modified }\end{array}$ & $\begin{array}{c}\text { Pick aceleration }(\% \mathrm{~g}) \\
\text { (Trifunac \& Brady, 1975) }\end{array}$ & $\begin{array}{c}\text { Value of the parameter } \\
\mathrm{D}_{\mathrm{s}}\end{array}$ \\
\hline I & $0.3-0.6$ & 1 \\
II & $0.6-1.1$ & 2 \\
III & $1.1-2.2$ & 3 \\
IV & $2.2-4.5$ & 4 \\
V & $4.5-8.9$ & 5 \\
VI & $8.9-17.7$ & 6 \\
VII & $17.7-35.4$ & 7 \\
VIII & $35.4-70.5$ & 8 \\
IX & $70.5-140.8$ & 9 \\
X & $140.8-280.8$ & 10 \\
XI & $280.8-560-4$ & 11 \\
XII & $>560.4$ & 12 \\
\hline
\end{tabular}

The trigger by rain (Dll) considers rainfall intensities potentially generating landslides. The predicted maximum rain $(\mathrm{mr}$ in $\mathrm{mm}$ ) in 24 hours over a period of 100 years is used, applying the Gumbel extreme value distribution type I or LogPearson type III to time series with more than 10 years of records (Mora, et al., 1992). The heavier the rain, the larger the Dll (Table 6).

Table 6. Assessment of the parameter trigger by rain $\mathrm{D}_{11}$. Source: Mora, et al., (1992)

\begin{tabular}{ccc}
\hline $\begin{array}{c}\text { Maximum rain in } 24 \text { hours, return period }=100 \text { years } \\
{[\mathrm{mm}]}\end{array}$ & Description & $\begin{array}{c}\text { Value of the parameter } \\
\mathrm{D}_{11}\end{array}$ \\
\hline$<100$ & Very low & 1 \\
$100-200$ & Low & 2 \\
$200-300$ & Medium & 3 \\
$300-400$ & High & 4 \\
$>400$ & Very high & 5 \\
\hline
\end{tabular}

Mora et al. (1992) divided the range of values for a study area into 5 classes of susceptibility (Table 6).

Table 7. Classes of landslide susceptibility Source: Mora, et al., (1992)

\begin{tabular}{ccc}
\hline Class & Description & Characteristic \\
\hline I & Very Low & Stable sectors \\
II & Low & Stable sectors that require \\
& & $\begin{array}{c}\text { corrective action when building } \\
\text { large structures }\end{array}$ \\
\hline
\end{tabular}




\begin{tabular}{|c|c|c|}
\hline III & Moderate (Medium) & $\begin{array}{c}\text { Sectors requiring geotechnical } \\
\text { studies and improvements to build } \\
\text { structures }\end{array}$ \\
\hline IV & High & $\begin{array}{l}\text { High probability of landslide }(< \\
50 \%) \text { in case of large magnitude } \\
\text { earthquakes and intense rain }\end{array}$ \\
\hline V & Very high & $\begin{array}{c}\text { Very high probability of landslide } \\
(>50 \%) \text { in case of large magnitude } \\
\text { earthquakes or intense rain }\end{array}$ \\
\hline
\end{tabular}

\section{Results}

The employed methodology allowed us to model the degree of slide susceptibility within the region studied. The calculation to obtain passive elements (PE) included the multiplication of the lithological susceptibility, soil moisture and slope parameters.

In terms of lithological susceptibility, the territory of Santo Domingo has lavas, tuffs, ignimbrites, deposits of pumice, ash and lahar flow. The lavas are very hard and resistant to weathering, as are the ignimbrites. Conversely, the tuff and pumice flows are softer and less resistant to weathering; recent ash and lahar flows have intermediate geotechnical characteristics (Astorga et al., 2011). Clay soils derived from ash are expansive and therefore, low resistance to effort. In accordance with the above, the categories of Mora-Varhson-Mora for the lithological susceptibility of Santo Domingo are 2 (moderate), 3 (medium) and 4 (high).

Using data (more than 20 years) from seven weather stations surrounding the canton, we obtained the monthly average of rain which allowed us to perform an interpolation of the data and generate a map of moisture that gave two categories 2 (low) and 3 (medium).

Regarding slopes, in Santo Domingo, all categories (Figure 2) proposed by the Mora-Varhson-Mora methodology are present. As is illustrated in Figure 2, the relief of Santo Domingo is generally flat and high angle slopes occur along the course of the rivers.

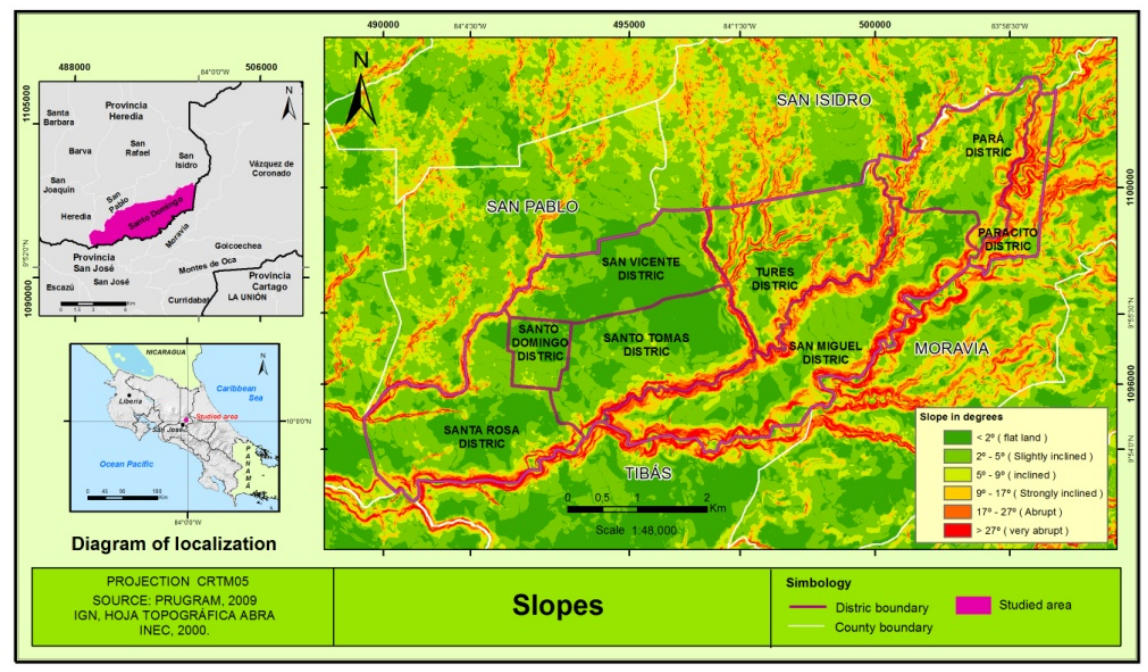

Figure 2. Maps of slopes for Santo Domingo

The trigger factor term (D) resulted from the sum of both the seismicity trigger term and the rain trigger term. The seismicity is valued at category 8 over the entire territory since it has been recognized the potential exists for maximum intensities of VIII and IX (Linkimer, 2008) and peak acceleration between 5.01 and $6.00 \mathrm{~m} / \mathrm{s}^{2}$ (Benito et al., 2012) resulting in percentages of acceleration of gravity in the range of 51 and 61.

According to data, the maximum rainfall over 24 hours in Santo Domingo for a return period of 100 years varies between 113 and $169 \mathrm{~mm}$, which means that the entire area received a score of category 2 (low) for extreme precipitation.

When combining the passive and active elements in the formula, we determined that the places with the 
susceptibility to slip in the canton of Santo Domingo are all in river canyons, such as the canyons of the Virilla, Tibás, Bermúdez, Pará and Paracito rivers. (Figures 1 and 3).

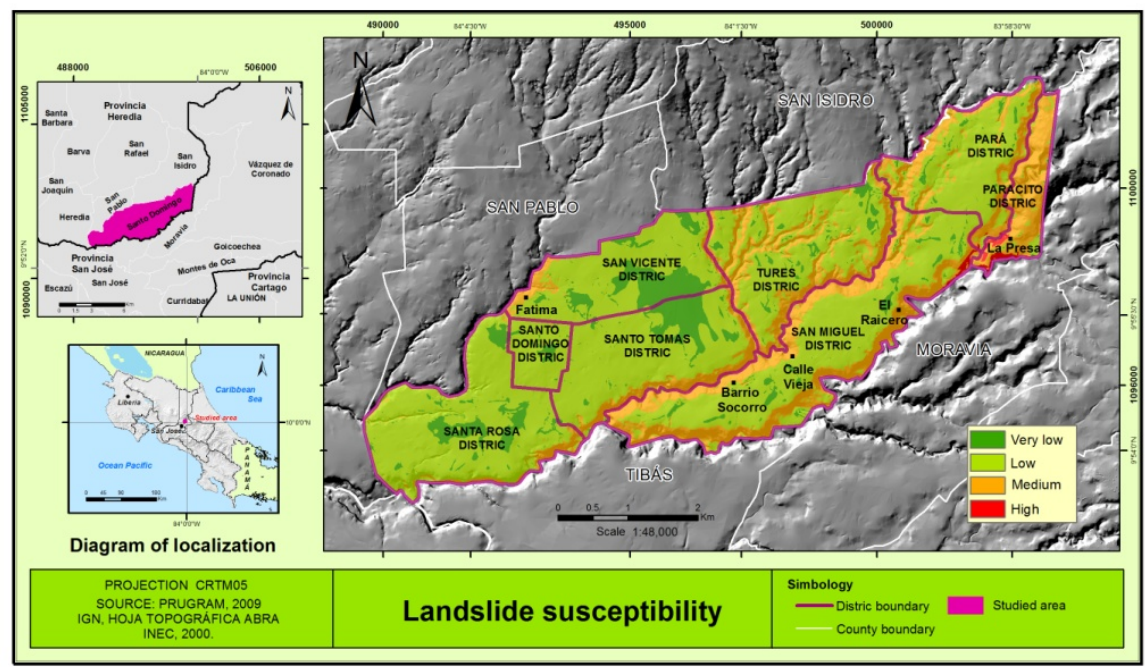

Figure 3. Map of landslide potential in Santo Domingo

Figure 3 highlights five areas with potential to slip, which include the Western part of the San Vicente district (e.g., Monte Carmelo and Fatima communities, see Figure 4), the area where the deadly 2008 landslide occurred (i.e., Barrio El Socorro), Calle Vieja, El Raicero in San Miguel and the community known as La Presa in the District of Paracito. First, Fatima and Monte Carmelo are located on the southern slope of the Río Bermúdez (Figure 4) and as will be discussed later, it is an area that already shows evidence of soil movement, suggesting that this area needs to be carefully monitored in order to ensure the future safety of those who live there.

Second, based on the methodology employed here, the area where the 2008 landslide (Barrio Socorro) occurred is classified as having "medium" potential for landslides, which confirms that landslides can occur even in those areas not at "high" risk. In this specific case, land use decisions shaped additional risks not measured in the model. Currently, there is a tomato plantation in that area, which replaced a coffee plantation. The change in land use in an area on a steep slope resulted in less vegetation cover, which can also cause landslides of differing magnitudes.

Third, Calle Vieja is a group of houses located on the slope of the Tibás river, which is also within the area of greatest landslide potential. And fourth, a similar situation arises in La Presa, which is a town at "high" risk based on this methodology. The steep slope and laharic soils contribute to this area's "high" risk.

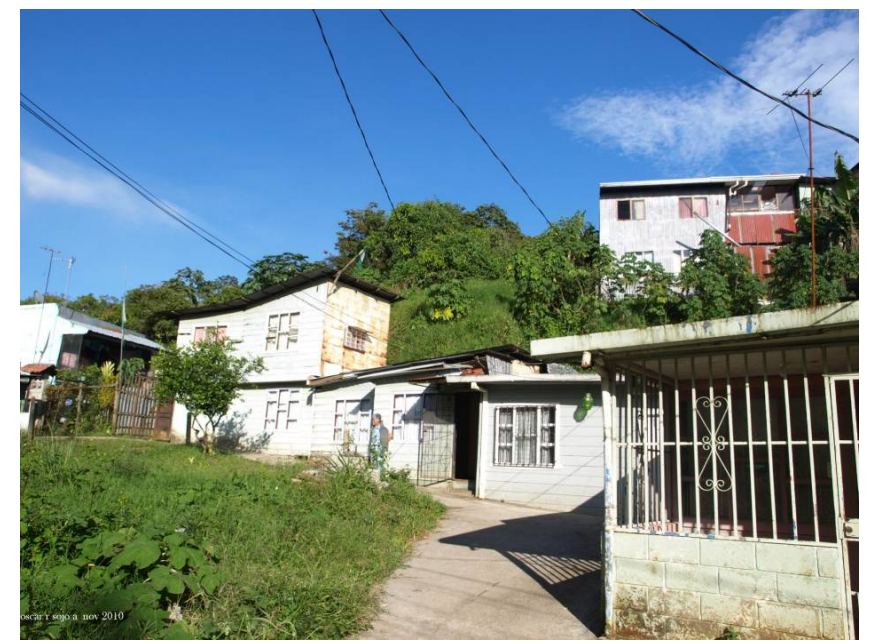

Figure 4. View of Barrio Fátima (below) y Monte Carmelo (above). Due to the limited space left by the slope, the owners opt for the vertical growth of the housing 
Another site affected by landslides is El Raicero (Figure 3), which today is cultivated for coffee by which does not become a threat to some infrastructure, but the instability it could be a problem for the road or for future heavy structures made without appropriate studies.

\section{Discussion}

The research confirms that the landslide potential is objectively low in much of Santo Domingo, but that there are areas of risk in zones of high slope formed by the action of rivers. The Barrio Socorro landslide in 2008 and what we discovered about the instability of the soil in Barrio Fátima and Monte Carmelo corroborate the findings of the model. As mentioned, a deadly landslide occurred on Saturday July 19, 2008 (Figure 5) in Barrio del Socorro, a neighborhood located within an area of Medium landslide potential. This landslide dragged two vehicles and two people into the Tibás river, one survived but the other perished.

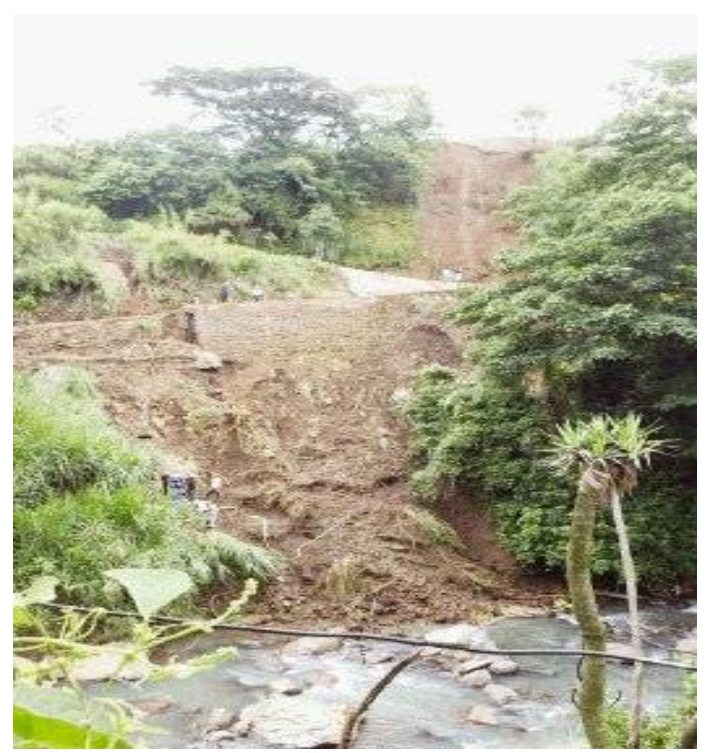

Figure 5. The July 192008 landslide of Barrio Socorro, Santo Domingo de Heredia. Courtesy Periódico Aldia

Field reconnaissance conducted during February and March of 2014 revealed that the soil in Barrio Fátima and Monte Carmelo already show signs of instability. As a result of the instability, soil is sloughing off in the backyards of some houses, and pressure is causing walls to curve and cracks to emerge in floors and walls (Figure 6), which suggest that the soil is moving toward the Bermúdez river.

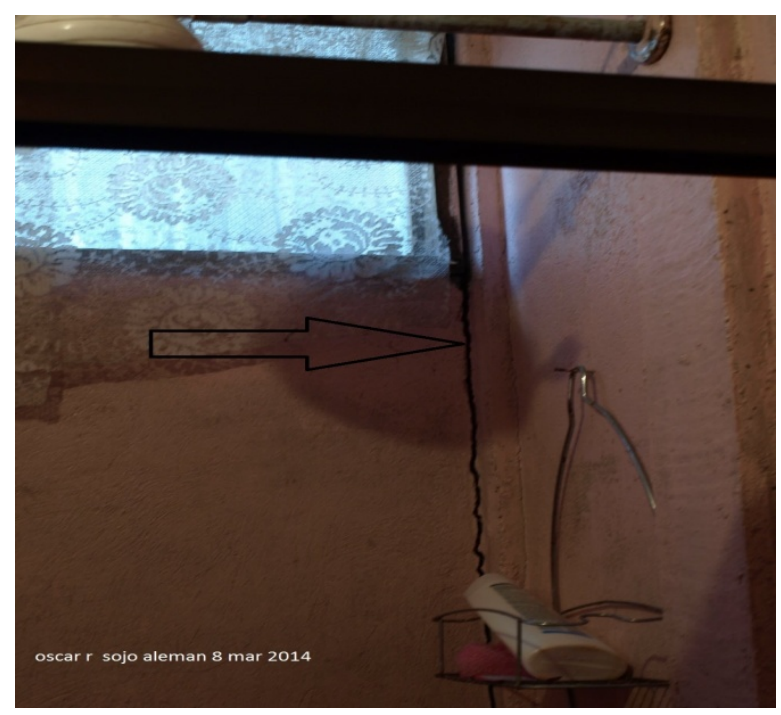

Figure 6. Cracks in the walls of a house in Barrio Fátima 
This study also confirms that the simple MVM methodology employed here is an efficient way to estimate the susceptibility of landslides over a relatively large area (this canton covers 25 square kilometers). Consideration of rain, which is done in this MVM methodology, as trigger for landslides is imperative in tropical countries. For example, rain triggered the 2008 Barrio del Socorro landslide. According to data from the Department of Climatology of the Costa Rican National Meteorological Institute (IMN), July of 2008 was an extremely rainy month throughout the country, with the central sector, which includes Santo Domingo, being especially hard hit as there was an excess of precipitation of $60 \%$ (Sanchez, 2008). A total of 8 tropical waves crossed Costa Rica in July 2008 and one of them hit the country the very day when the landslide occurred (IMN, 2008). In addition, there were very rainy days in the study area in the days preceding the deadly landslide. The IMN weather stations closest to the site recorded between 37 and $43 \mathrm{~mm}$ on July 19th 2008, (Table 7). Based on that, we estimated that the heavy rain ranged between 30 and $50 \mathrm{~mm}$ in the area of the slide on July 19, 2008. According to data presented in Table 7, there was excess rain in the areas surrounding the slide site, and therefore, the soils were very saturated with water, creating favorable conditions for the occurrence of a landslide.

Table 7. Rain on July 19, 2008 and total rain in July, 2008. The weather stations used are located relatively near the landslide's site

\begin{tabular}{|c|c|c|}
\hline Station & Rain on July 19,2008 (mm) & Total rain in July $2008(\mathrm{~mm})$ \\
\hline San Josecito & 37.4 & 300 \\
\hline Santa Lucía & 39.4 & 411 \\
\hline Tibás & 43.0 & 302 \\
\hline
\end{tabular}

In terms of limitations, the territory of Santo Domingo is relatively flat; a more rugged territory would have been desirable to demonstrate the efficiency of the MVM methodology. It is also necessary to report that no trials of direct shear strength or classification of rock massif were conducted because the studied terrain is very flat and secondly because there are no rock massifs in the canton. In terms of meteorological data, when the study was conducted, there was not a weather station in the canton that could provide local rain data and so rain data from nearby stations were used. Currently, there is a meteorological station in Santo Domingo and it is expected that future data will be used to improve the current estimates. It is estimated that the limitations do not significantly influence results although we recognize that they would have increased the accuracy of model. But in any case, the authors of the MVM method suggest that if doubts persist about the calculated landslide potential, in-depth studies of critical areas should be conducted (Mora et al., 2002).

This study is of the utmost importance for tropical countries with mountain belts, active tectonics and populations living on, or at the foot of, high angle slopes, as it is the case in Costa Rica. The results indicate the places where there could be landslides in the future and therefore help us to take action to prevent landslide disasters. This sort of analysis must be carried out in all 81 cantons in the country. The results from this type of analysis can be used to not only protect human lives but economic investments in public and private sectors. The findings are useful for disaster risk management officials in the Santo Domingo and will be shared with them.

\section{Conclusions}

By calculating landslide susceptibility using the Mora-Vahrson-Mora methodology, we determined that the landslide potential for Santo Domingo is relatively low and that the maximum probability of landslides is in areas with the greatest slope, along river canyons. Communities located in areas of "high" risk for sliding are Fatima and Monte Carmelo, Calle Vieja, and La Presa, which are all communities with significant population and housing density.

The results of the secondary data analyses reported here were corroborated by field observations in Fatima and Monte Carmelo where we witnessed insecure slope conditions and risk for residents of these neighborhoods. Cracks in the soil, subsidence of the ground, deformation of structures, and efflux of water through walls are all indicative of soil instability and water logged soil, which could favor major landslides. We recommend an urgent examination of the stability of the slopes in Fatima and Monte Carmelo, the evacuation of residual waters, and relocation of families located in this high risk area.

The July 19th 2008 landslide occurred after heavy precipitation and was shot by rain which confirms that rain is a very important trigger factor of landslides in tropical countries. 


\section{Acknowledgement}

Thanks to Luis Fernando Alvarado from the National Meteorological Institute of Costa Rica for supplying the meteorological information. Our gratitude to Sara Grinesky for improving the manuscript.

\section{References}

Alexander, E. D. (1995). A survey of the field of natural hazards and disaster studies. In Carrara, A., Guzzetti, F. Eds., Geographical Information Systems in Assessing Natural Hazards. Kluwer Academic Publisher, Dordrecht, The Netherlands, pp. 1-19. http://dx.doi.org/10.1007/978-94-015-8404-3_1

Alvarado, G. E., Mora, R., \& Peraldo, G. (2003). The June 2000 Arancibia Debris Avalanche and Block Slide. Landslide News, No 14/15.

Arias, O., \& Denyer, P. (1991). Estructura geológica de la región comprendida en las hojas topográficas Abra, Caraigres, Candelaria y Río Grande, Costa Rica. Revista Geológica de América Central, 12, 61-74.

Astorga, A., Mende, A., \& Valerín, E. (2011). Vulnerabilidad Hidrogeológica del Cantón de Santo Domingo. Informe para la Municipalidad de Santo Domingo, pp. 111.

Barrantes, G., Barrantes, O., \& Nuñez, O. (2011). Efectividad de la metodología Mora-Vahrson-Mora modificada en el caso de los deslizamientos provocados por el terremoto de Cinchona, Costa Rica. Revista Geográfica de América Central, 2(47).

Benito, M., Lindholm, C., Camacho, E., Climent, A. Marroquin, G., Molina, E., Rojas, W., Escobar, J., Talavera, E., Alvarado, G., \& Tomas, Y., (2012). A New Evaluation of Seismic Hazard for the Central America Region. Bulletin of the Seismological Society of America, 102(2), 504-523. http://dx.doi.org/10.1785/0120110015

Dai, F., Lee, C., \& Ngai, Y. (2002). Landslide risk assessment and management: an overview. Engineering Geology, 64, 65-87. http://dx.doi.org/10.1016/S0013-7952(01)00093-X

Dasa, I., S., C., Steina, S., \& Hacka, R. (2010). Landslide susceptibility assessment using logistic regression and its comparison with a rock mass classification system, along a road section in the northern Himalayas (India). Geomorphology, 114(4), 627-637. http://dx.doi.org/10.1016/j.geomorph.2009.09.023

Guzzeti, F. (2000). Landslide fatalities and the evaluation of landslide risk in Italy. Engineering Geology, 58, 89-107. http://dx.doi.org/10.1016/S0013-7952(00)00047-8

Guzzetti, F., Carrara, A., Cardinali, M., \& Reichenbach, P. (1999). Landslide hazard evaluation: A review of current techniques and their application in a multi-scale study, Central Italy. Geomorphology, 31, 181-216. http://dx.doi.org/10.1016/S0169-555X(99)00078-1

Guzzetti, F., Reichenbach, P., Cardinali, M., Galli, M., \& Ardizzone, F. (2005). Probabilistic landslide hazard $\begin{array}{lllll}\text { assessment at the basin } \quad \text { scale. } & \text { Geomorphology, }\end{array}$ http://dx.doi.org/10.1016/j.geomorph.2005.06.002

Larsen, M., \& Torres, A. (1998), The Frequency and Distribution of Recent Landslides in three Montane Tropical Regions of Puerto Rico: Geomorphology, 24(4), 309-331. http://dx.doi.org/10.1016/S0169-555X(98)00023-3

Linkimer, L. (2008). Relationship between peak ground acceleration and Modified Mercalli intensity in Costa Rica. Revista Geológica de América Central, 38, 81-94.

Mora, R. (1993). Después de 28 años de actividad del deslizamiento San Blas, Cartago (Costa Rica). Geoistmo, Vol. $V V, \mathrm{~N}^{\circ}(1 \mathrm{y}, 2), 113-123$.

Mora, R. (2001). El deslizamiento de Las Lagunas Arancibia, Costa Rica: un desastre dos veces anunciado. EIRD Informa-América Latina y el Caribe. Número, (2),. 28-30.

Mora, R., \& Soto, G. (1990). Landslide and Avalanche on Itiquís, Alajuela, Costa Rica. Landslides News IV.

Mora, R., Cerdas, A., Molina, F., \& Vega, E. (1990). Caracterización Geológica del Deslizamiento Chiz (Turrialba, Provincia de Cartago, Costa Rica): Amenaza y Prevención. Revista Geológica de América. Central, 11, 59-68.

Mora, R., Saravia, M., Chavarría, R., \& Leandro, F. (1989). Análisis Preliminar de Estabilidad de Laderas, Valle de Ujarrás, Paraíso Cartago, Costa Rica. Geoistmo, Vol. III, Núm. (2).

Mora, R., Vahrson, W., \& Mora, S. (1992). Mapa de Amenaza de Deslizamientos, Valle Central, Costa Rica. Centro de Coordinación para la Prevención de Desastres Naturales en América Central (CEPREDENAC). 
Informe interno.

Mora. R., Cháves. J., \& Vásquez, M. (2002). Zonificación de la susceptibilidad al deslizamiento: Resultados obtenidos para la Península de Papagayo mediante la modificación del método Mora \& Vahrson (Mora et al., 1992). Memoria del tercer curso internacional sobre microzonificación y su aplicación en la mitigación de desastres. Lima, Perú, 38-46.

Peraldo, G., \& Molina, F. (1993). Reconstrucción Histórica del deslizamiento de Santiago de Puriscal. Revista Geológica de América Central, 16, 85-94.

Pérez, W., Alvarado, G., \& Gans, P. (2004). The 322 ka Tiribí Tuff: stratigraphy, geochronology and mechanisms of deposition of the largest and most recent ignimbrite in the Valle Central, Costa Rica. Bulletin of Volcanology, (2006)69, 25-40. http://dx.doi.org/10.1007/s00445-006-0053-x.

Pradhan, B. (2010). Remote sensing and GIS-based landslide hazard analysis and cross-validation using multivariate logistic regression model on three test areas in Malaysia. Advances in Space Research, 45(10), 1244-1256. http://dx.doi.org/10.1016/j.asr.2010.01.006

Rosenfeld, C. L. (1994). The geomorphological dimensions of natural disasters. Geomorphology, 10, $27-36$. http://dx.doi.org/10.1016/0169-555X(94)90006-X

Sánchez, M. (2008). Boletín Meteorológico XXXIII, julio, Instituto Meteorológico Nacional, ISSN-1659-0465.

Segura, G., Badilla, E., \& Obando, L. (2011). Susceptibilidad al deslizamiento en el corredor Siquirres-Turrialba, Revista Geológica de América Central, 45, 101-121, ISSN: 0256-7024.

Trifunac, M. D., \& Brady, A. G. (1975). On the correlation of seismic intensity scales with the peaks of recorded ground motion, Bulletin Seismological Society America, 65, 139-162.

Van Zuidam, R. (1986). Aerial photointerpretation in terrain analysis and geomorphologic mapping, Smits Publishers, The Hague, p442.

\section{Copyrights}

Copyright for this article is retained by the author(s), with first publication rights granted to the journal.

This is an open-access article distributed under the terms and conditions of the Creative Commons Attribution license (http://creativecommons.org/licenses/by/3.0/). 